\title{
Liver transplantation for hepatic epithelioid hemangioendothelioma: The Canadian multicentre experience
}

\author{
Carmine G Nudo $M D^{1}$, Eric $M$ Yoshida $M D^{2}$, Vincent G Bain $M D^{3}$, Denis Marleau $M D^{4}$, Phil Wong $M D^{5}$, \\ Paul J Marotta $M D^{6}$, Eberhard Renner $M D^{7}$, Kymberly D Watt $M D^{8}$, Marc Deschênes $M D^{1}$
}

CG Nudo, EM Yoshida, VG Bain, et al. Liver transplantation for hepatic epithelioid hemangioendothelioma: The Canadian multicentre experience. Can J Gastroenterol 2008;22(10):821824.

INTRODUCTION: Hepatic epithelioid hemangioendothelioma (HEHE) is a rare entity. At the present time, there is no standardized effective therapy. Liver transplantation (LT) has emerged as a treatment for this rare tumour.

OBJECTIVE: To evaluate the outcome of liver transplantation for HEHE at eight centres across Canada.

METHODS: The charts of patients who were transplanted for HEHE at eight centres across Canada were reviewed.

RESULTS: A total of 11 individuals (eight women and three men) received a LT for HEHE. All LTs were performed between 1991 and 2005. The mean $( \pm$ SD) age at LT was $38.7 \pm 13$ years. One patient had one large liver lesion $(17 \mathrm{~cm} \times 14 \mathrm{~cm} \times 13 \mathrm{~cm})$, one had three lesions, one had four lesions and eight had extensive (five or more) liver lesions. One patient had spleen involvement and two had involved lymph nodes at the time of transplantation. The mean duration of follow-up was $78 \pm 63$ months (median 81 months). Four patients $(36.4 \%)$ developed recurrence of HEHE with a mean time to recurrence of $25 \pm 25$ months (median 15.6 months) following LT. The calculated survival rate following LT for HEHE was $82 \%$ at five years.

CONCLUSIONS: The results of LT for HEHE are encouraging, with a recurrence rate of $36.4 \%$ and a five-year survival rate of $82 \%$. Further studies are needed to help identify patients who would benefit most from LT for this rare tumour.

Key Words: Hepatic epithelioid hemangioendothelioma; Liver; Transplantation

【epatic epithelioid hemangioendothelioma (HEHE) is a 1 rare indication for liver transplantation (LT). Epithelioid hemangioendothelioma is a rare vascular tumour that was first described by Weiss and Enzinger in 1982 (1). It has been described in many different organs such as the spleen, bone, brain, meninges, breast, heart, head and neck, soft tissue, stomach and lymph nodes (1-6). In 1984, Ishak et al (7) reported a series of 32 patients with HEHE.

\section{Transplantation hépatique pour}

hémangioendothéliome épithélioïde hépatique : Expérience multicentrique canadienne

INTRODUCTION : L'hémangioendothéliome épithélioïde hépatique (HEÉH) est une entité clinique rare pour laquelle il n'existe aucun traitement standardisé efficace à l'heure actuelle. La transplantation hépatique $(\mathrm{TH})$ est devenue le traitement indiqué pour cette tumeur rare.

OBJECTIF : Évaluer l'issue de la transplantation hépatique pour l'HEÉH dans huit centres canadiens.

MÉTHODES : Les dossiers de patients qui ont reçu une transplantation pour HEÉH dans huit centres hospitaliers canadiens ont été passés en revue.

RÉSULTATS : En tout, 11 personnes ( 8 femmes et 3 hommes) ont reçu une TH pour HEÉH. Toutes les TH ont été réalisées entre 1991 et 2005. Lâge moyen ( \pm É.-T.) au moment de la TH était de 38,7 \pm 13 ans. Un patient présentait une volumineuse lésion hépatique $(17 \mathrm{~cm} \times 14 \mathrm{~cm}$ $\times 13 \mathrm{~cm}$ ), un autre présentait trois lésions, un autre encore en présentait quatre et huit avaient des lésions plus nombreuses (cinq ou plus). Un patient présentait une atteinte splénique et deux, une atteinte des ganglions lymphatiques au moment de la transplantation. La durée moyenne du suivi a été de $78 \pm 63$ mois (médiane 81 mois). Quatre patients $(36,4 \%)$ ont présenté une récurrence dans un délai moyen de $25 \pm 25$ mois (médiane 15,6 mois) après la TH. Le taux de survie calculé avec la TH pour HEÉH a été de $82 \%$ à cinq ans.

CONCLUSION : Les résultats de la TH pour HEÉH sont encourageants, avec un taux de récurrence de $36,4 \%$ et un taux de survie à cinq ans de $82 \%$. D'autres études s'imposent pour faciliter l'identification des patients qui bénéficieraient le plus de la TH pour cette rare tumeur.

\footnotetext{
${ }^{1}$ McGill University, Montréal, Québec; ${ }^{2}$ University of British Columbia, Vancouver, British Columbia; ${ }^{3}$ University of Alberta, Edmonton,

Alberta; ${ }^{4}$ Université de Montréal, Montréal, Québec; ${ }^{5}$ University of Toronto, Toronto, Ontario; ${ }^{6}$ University of Western Ontario, London,

Ontario; ${ }^{7}$ University of Manitoba, Winnipeg, Manitoba; ${ }^{8}$ Dalhousie University, Halifax, Nova Scotia

Correspondence: Dr Carmine G Nudo, Royal Victoria Hospital, Department of Gastroenterology, 687 Pine Avenue West, Montréal, Québec

H3A 1A1. Telephone 514-934-1934, fax 514-843-1421, e-mail carmine.nudo@mail.mcgill.ca

Received for publication December 11, 2007. Accepted May 27, 2008
} 
TABLE 1

Patients transplanted for hepatic epithelioid hemangioendothelioma

\begin{tabular}{|c|c|c|c|c|c|c|c|c|c|c|c|c|}
\hline \multirow[b]{2}{*}{ Case } & \multirow[b]{2}{*}{$\begin{array}{l}\text { Age, } \\
\text { years }\end{array}$} & \multirow[b]{2}{*}{ Sex } & \multirow[b]{2}{*}{$\begin{array}{c}\text { Follow-up, } \\
\text { months }\end{array}$} & \multirow[b]{2}{*}{$\begin{array}{c}\text { Liver } \\
\text { lesions, } \mathrm{n}\end{array}$} & \multirow[b]{2}{*}{$\begin{array}{c}\text { Metastatic } \\
\text { location }\end{array}$} & \multirow{2}{*}{$\begin{array}{l}\text { Adjuvant } \\
\text { therapy } \\
\text { before LT }\end{array}$} & \multicolumn{2}{|c|}{ Recurrence } & \multirow[b]{2}{*}{$\begin{array}{l}\text { Therapy for } \\
\text { recurrence }\end{array}$} & \multirow[b]{2}{*}{ Death } & \multirow{2}{*}{$\begin{array}{l}\text { Time } \\
\text { to death, } \\
\text { months }\end{array}$} & \multirow[b]{2}{*}{$\begin{array}{c}\text { Cause } \\
\text { of death }\end{array}$} \\
\hline & & & & & & & Location & $\begin{array}{l}\text { Time, } \\
\text { months }\end{array}$ & & & & \\
\hline \multirow[t]{2}{*}{1} & 27 & $\mathrm{~F}$ & 61.0 & 4 & - & Interferon sc & Liver & 12 & Surgical & Yes & 61 & Unknown \\
\hline & & & & & & & Lung & 60 & resection & & & \\
\hline 2 & 52 & $M$ & 168.0 & $>5$ & - & - & - & - & - & No & - & - \\
\hline \multirow[t]{2}{*}{3} & 31 & $M$ & 189.0 & $1^{*}$ & Spleen & Splenectomy & Liver & 61 & $\begin{array}{l}\text { Surgical } \\
\text { resection }\end{array}$ & No & - & - \\
\hline & & & & & & & & & Repeat LT & & & \\
\hline 4 & 24 & $M$ & 112.0 & $>5$ & Unknown & - & - & - & - & No & - & - \\
\hline 5 & 51 & $\mathrm{~F}$ & 102.0 & $>5$ & - & - & Bone & 19 & Radiotherapy & No & - & - \\
\hline 6 & 51 & $\mathrm{~F}$ & 100.0 & $>5$ & Lymph node & - & - & - & - & No & - & - \\
\hline 7 & 30 & $\mathrm{~F}^{\dagger}$ & 0.5 & $>5$ & Lymph node & Adriamycin & - & - & - & Yes & 0.5 & HAT \\
\hline 8 & 18 & $\mathrm{~F}$ & 81.0 & $>5$ & - & $\begin{array}{l}\text { Surgical } \\
\text { resection }\end{array}$ & - & - & - & No & - & - \\
\hline 9 & 51 & $\mathrm{~F}$ & 24.0 & $3^{\ddagger}$ & - & - & - & - & - & No & - & - \\
\hline 10 & 52 & $\mathrm{~F}$ & 11.0 & $>5$ & - & - & $\begin{array}{l}\text { Liver, } \\
\text { spleen }\end{array}$ & 7 & $\begin{array}{l}\text { Pegylated } \\
\text { interferon }\end{array}$ & Yes & 11 & Tumour \\
\hline 11 & 39 & $\mathrm{~F}$ & 12.5 & $>5$ & - & - & - & - & - & No & - & - \\
\hline
\end{tabular}

Table includes patient characteristics at the time of transplantation, as well as data on recurrence and death. *Liver lesion was $17 \mathrm{~cm} \times 14 \mathrm{~cm} \times 13 \mathrm{~cm}$ in size; †Transplanted twice for initial graft failure; $¥$ Liver lesions were $3.5 \mathrm{~cm}, 4 \mathrm{~cm}$ and $10 \mathrm{~cm}$ in size. F Female; HAT Hepatic artery thrombosis; LT Liver transplantation; M Male; sc Subcutaneous

Most patients with HEHE are asymptomatic at the time of diagnosis. If symptoms are present, they are nonspecific, and may include weight loss and right upper quadrant pain. Some patients may also present with jaundice and liver failure (7). Hepatic failure is likely due to replacement of liver parenchyma by the tumour.

Physical findings may include hepatomegaly, a palpable mass or jaundice (9). Many patients will have mild elevations in serum bilirubin, alkaline phosphatase and aspartate aminotransferase levels. Alpha-fetoprotein and cancer antigen 19-9 levels are normal. Carcinoembryonic antigen may be elevated (10).

Lesions are often hypoechoic on ultrasound $(11,12)$, but may have a mixed echotexture or be hyperechoic (13). Typical computed tomography findings include hypoattenuated tumour in both lobes that coalesce to form larger confluent regions in a peripheral or subcapsular distribution. A halo or target pattern of enhancement can be seen in larger lesions $(11,12)$. The extent of lesions may be better appreciated with unenhanced computed tomography (12). Calcifications may be present in $20 \%$ of patients (10). On magnetic resonance imaging, lesions are hypointense relative to normal liver on unenhanced $\mathrm{T} 1$-weighted images and heterogeneously increased signal intensity on T2-weighted images $(4,8,9,14,15)$.

Histological findings are characterized by epithelioid or histiocytoid morphology (14). Intravascular spread into terminal hepatic venules and portal vein branches is common (9). Vascular characteristics of the tumour can be confirmed with staining for factor VIII-related antigen and other endothelial cell markers (CD31, CD34) (10).

The natural history of HEHE is unpredictable, with a clinical course between benign hemangioma and angiosarcoma $(10,14,16)$. Metastases have been reported in $27 \%$ of patients and most commonly occur in the lungs (3). The mortality rate is reported at more than $65 \%$. HEHE can be treated with liver resection, orthotopic LT, chemotherapy, radiotherapy or immunotherapy (9). Because HEHE is rare, the effectiveness of these therapies has not been formally assessed.

The aim of the present study was to evaluate the Canadian experience of LT for HEHE.

\section{METHODS}

All eight centres performing LT or involved in the care of LT patients participated in the study. The charts of patients transplanted for HEHE at eight centres across Canada were reviewed. Data collected included patient age, sex, indication for LT, duration of follow-up, tumour recurrence, therapy for the tumour before transplantation and for recurrences, and patient survival.

\section{Statistical analysis}

The data collected were used to calculate the rate of and time to recurrence and death. Kaplan-Meier survival curves for disease-free survival and patient survival for patients transplanted for HEHE were also calculated.

\section{RESULTS}

A total of 11 individuals underwent LT for HEHE. All LTs were performed between 1991 and 2005. All liver grafts were from deceased donors.

The characteristics of patients transplanted for HEHE are shown in Table 1. Eleven patients received a LT for HEHE, of whom eight were female and three were male. The mean $( \pm$ SD) age at transplantation was $38.7 \pm 13$ years. One patient underwent an early repeat LT for hepatic artery thrombosis and died soon after the second LT. One patient had one large liver lesion $(17 \mathrm{~cm} \times 14 \mathrm{~cm} \times 13 \mathrm{~cm})$, one had three lesions, one had four lesions and nine had extensive (five or more) liver lesions. One patient had spleen involvement and two had positive lymph nodes at the time of transplantation. 


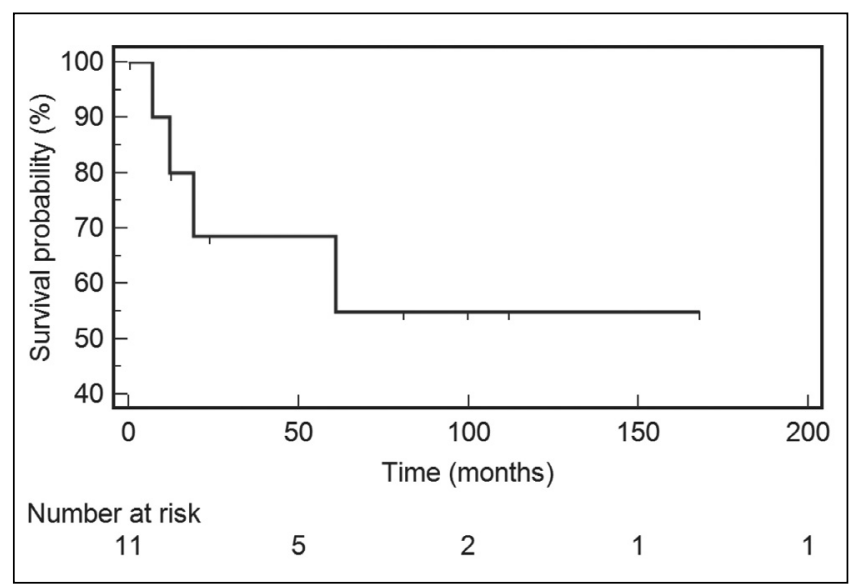

Figure 1) Kaplan-Meier curve for disease-free survival following liver transplantation for hepatic epithelioid hemangioendothelioma. Censored patients are marked on the curve and the number at risk are listed below the graph

The mean duration of follow-up after transplantation was $78 \pm 63$ months (median 81 months). Four patients received adjuvant therapy for HEHE before LT (interferon therapy $[n=1]$, splenectomy $[n=1]$, adriamycin therapy $[n=1]$ and surgical resection $[\mathrm{n}=1])$.

Four patients $(36.4 \%)$ developed recurrence of HEHE following LT, with a mean time to recurrence of $25 \pm 25$ months (median 15.6 months). Two patients with recurrence in the liver were treated with tumour resection; one of these patients underwent a repeat LT (Table 1). One patient with bone recurrence was treated with radiotherapy for pain. A fourth patient with liver and spleen recurrence was treated with pegylated interferon.

The one-year disease-free survival rate was $80 \%$, and the three- and five-year disease-free survival rates were $69 \%$ (Figure 1). Beyond five years, the disease-free survival rate was $55 \%$.

Three patients $(27 \%)$ died during the follow-up period (Table 1). One patient died from tumour-related complications, one secondary to hepatic artery thrombosis and the third of unknown cause. The calculated survival rate following LT for HEHE was $82 \%$ at five years (Figure 2). Beyond five years, the survival rate was $70 \%$.

\section{DISCUSSION}

Because HEHE is rare, no therapy has been clearly established. LT has emerged as one possible therapy for these conditions. The aim of our study was to evaluate the Canadian experience of LT for HEHE.

In our study, the disease-free survival rate was $80 \%$ at one year, and 69\% at three and five years for HEHE following LT (Figure 1). The overall survival rate was $82 \%$ at one, three and five years (Figure 2 ). Our results are comparable with previously published data. In one single-centre report (17), 16 patients were transplanted for HEHE with a median follow-up period of 4.5 years ( 54 months). The disease-free survival rates at one, three and five years were $81.3 \%, 68.8 \%$ and $60.2 \%$, respectively. The survival rates were $100 \%, 87.5 \%$ and $73.3 \%$, respectively. Another published series (18) of 21 patients had a 33\% incidence of tumour recurrences and a two-year survival rate of $82 \%$. In a review (9) of 434 published cases of HEHE,

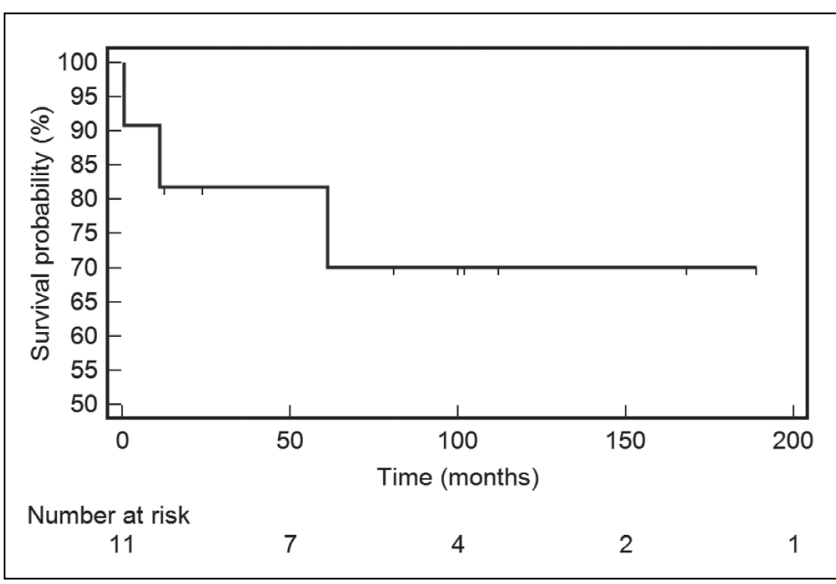

Figure 2) Kaplan-Meier curve for overall patient survival following liver transplantation for hepatic epithelioid hemangioendothelioma. Censored patients are marked on the curve and the number at risk are listed below the graph

data on therapy were available for 286 patients. Therapy included LT in 128 patients, no therapy in 71, chemotherapy and radiotherapy in 60 , and liver resection in 27 . The one- and five-year patient survival rates following LT were $96 \%$ and $54.5 \%$, respectively. The one- and five-year survival rates were $39.3 \%$ and $4.5 \%$, respectively, with no treatment; $73.3 \%$ and $30 \%$, respectively, following chemotherapy or radiotherapy; and $100 \%$ and $75 \%$, respectively, following liver resection. In one published series (15) of 10 cases of HEHE, six patients were treated without surgery, with a five-year survival rate of $67 \%$. Those treated with surgical resection had a three-year survival rate of $0 \%$.

Fifty-nine patients transplanted for HEHE were reported to the European Liver Transplant Registry (19). Fourteen patients $(23.7 \%)$ developed disease recurrence at a median time of 49 months and nine (15.3\%) died of recurrent disease. One-, five- and 10-year post-LT survival rates were $93 \%, 83 \%$ and $72 \%$, respectively. Disease-free survival rates were $90 \%, 82 \%$ and $64 \%$, respectively. Disease-free survival was not significantly influenced by pre-LT treatment, lymph node status, extrahepatic disease or vascular invasion.

The outcomes of LT for HEHE in the United States from the United Network for Organ Sharing database were recently published (20). One hundred ten patients with HEHE underwent 126 transplantations between 1987 and 2005. Patient survival rates at one and five years were $80 \%$ and $64 \%$, respectively. Allograft survival rates were $70 \%$ and $55 \%$, respectively. The results of the study indicated that pretransplant medical status correlated with patient survival. Of the 38 patients who died, 12 (32\%) had recurrent HEHE.

Most patients with HEHE have large, multifocal tumours at the time of diagnosis. Approximately 20\% die within two years after the diagnosis and only $20 \%$ survive more than five years after diagnosis (14). The benefit of liver resection for HEHE is restricted to patients with limited involvement of the liver. For patients with unresectable multifocal tumours, LT remains a reasonable treatment option, even in patients with extrahepatic liver disease $(21,22)$. The five-year survival rate of patients who underwent LT for HEHE in our study and that of patients in previously published papers are comparable with the survival rate of patients transplanted for cirrhosis (23). 
HEHE should be considered in the differential diagnosis of all patients with a hepatic mass. Liver resection should be considered for patients with limited disease. LT should be considered for patients with extensive disease. The results of LT for HEHE are encouraging, with a recurrence rate of $36.4 \%$ and a five-year survival rate of $82 \%$, which is comparable with LT for cirrhosis. Further studies are needed to help identify patients who would benefit most from liver transplantation.

\section{REFERENCES}

1. Weiss SW, Enzinger FM. Epithelioid hemangioendothelioma: A vascular tumor often mistaken for a carcinoma. Cancer 1982;50:970-81.

2. Tiu CM, Chou YH, Wang HT, Chang T. Epithelioid hemangioendothelioma of spleen with intrasplenic metastasis: Ultrasound and computed-tomography appearance. Comput Med Imaging Graph 1992;16:287-90.

3. Weiss SW, Ishak KG, Dail DH, Sweet DE, Enzinger FM. Epithelioid hemangioendothelioma and related lesions. Semin Diagn Pathol 1986;3:259-87.

4. Marchiano D, Fisher F, Hofstetter S. Epithelioid hemangioendothelioma of the heart with distant metastases. A case report and literature review. J Cardiovasc Surg (Torino). 1993;34:529-33.

5. Ellis GL, Kratochvil FJ III. Epithelioid hemangioendothelioma of the head and neck: A clinicopathologic report of twelve cases. Oral Surg Oral Med Oral Pathol 1986;61:61-8.

6. Lee KC, Ng WF, Chan JK. Epithelioid haemangioendothelioma presenting as a gastric polyp. Histopathology 1988;12: 335-7.

7. Ishak KG, Sesterhenn IA, Goodman ZD, Rabin L, Stromeyer FW. Epithelioid hemangioendothelioma of the liver: A clinicopathologic and follow-up study of 32 cases. Hum Pathol 1984;15:839-52.

8. Hertl M, Cosimi AB. Liver transplantation for malignancy. Oncologist 2005;10:269-81.

9. Mehrabi A, Kashfi A, Fonouni H, et al. Primary malignant hepatic epithelioid hemangioendothelioma: A comprehensive review of the literature with emphasis on the surgical therapy. Cancer 2006;107:2108-21.
10. Makhlouf HR, Ishak KG, Goodman ZD. Epithelioid hemangioendothelioma of the liver: A clinicopathologic study of 137 cases. Cancer 1999;85:562-82.

11. Furui S, Itai Y, Ohtomo K, et al. Hepatic epithelioid hemangioendothelioma: Report of five cases. Radiology 1989;171:63-8.

12. Radin DR, Craig JR, Colletti PM, Ralls PW, Halls JM. Hepatic epithelioid hemangioendothelioma. Radiology 1988;169:145-8.

13. Miller WJ, Dodd GD III, Federle MP, Baron RL. Epithelioid hemangioendothelioma of the liver: Imaging findings with pathologic correlation. AJR Am J Roentgenol 1992;159:53-7.

14. Lauffer JM, Zimmermann A, Krahenbuhl L, Triller J, Baer HU. Epithelioid hemangioendothelioma of the liver. A rare hepatic tumor. Cancer 1996;78:2318-27.

15. Weitz J, Klimstra DS, Cymes K, et al. Management of primary liver sarcomas. Cancer 2007;109:1391-6.

16. Zhang W, Jambulingam PS, Silva MA, et al. Orthotopic liver transplantation for epithelioid haemangioendothelioma. Eur J Surg Oncol 2007;33:898-901.

17. Madariaga JR, Marino IR, Karavias DD, et al. Long-term results after liver transplantation for primary hepatic epithelioid hemangioendothelioma. Ann Surg Oncol 1995;2:483-7.

18. Penn I. Hepatic transplantation for primary and metastatic cancers of the liver. Surgery 1991;110:726-734; discussion 734-5.

19. Lerut JP, Orlando G, Adam R, et al; European Liver Transplant Registry. The place of liver transplantation in the treatment of hepatic epitheloid hemangioendothelioma: Report of the European liver transplant registry. Ann Surg 2007;246:949-57.

20. Rodriguez JA, Becker NS, O’Mahony CA, Goss JA, Aloia TA. Long-term outcomes following liver transplantation for hepatic hemangioendothelioma: The UNOS experience from 1987 to 2005. J Gastrointest Surg 2008;12:110-6.

21. Lerut JP, Orlando G, Sempoux C, et al. Hepatic haemangioendothelioma in adults: Excellent outcome following liver transplantation. Transpl Int 2004;17:202-7.

22. Ben-Haim M, Roayaie S, Ye MQ, et al. Hepatic epithelioid hemangioendothelioma: Resection or transplantation, which and when? Liver Transpl Surg 1999;5:526-31.

23. Forman LM, Lewis JD, Berlin JA, Feldman HI, Lucey MR. The association between hepatitis $\mathrm{C}$ infection and survival after orthotopic liver transplantation. Gastroenterology 2002;122:889-96. 


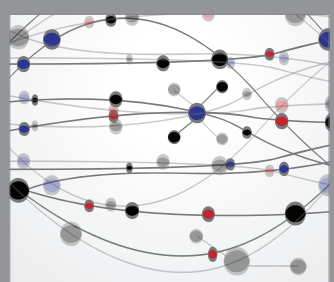

The Scientific World Journal
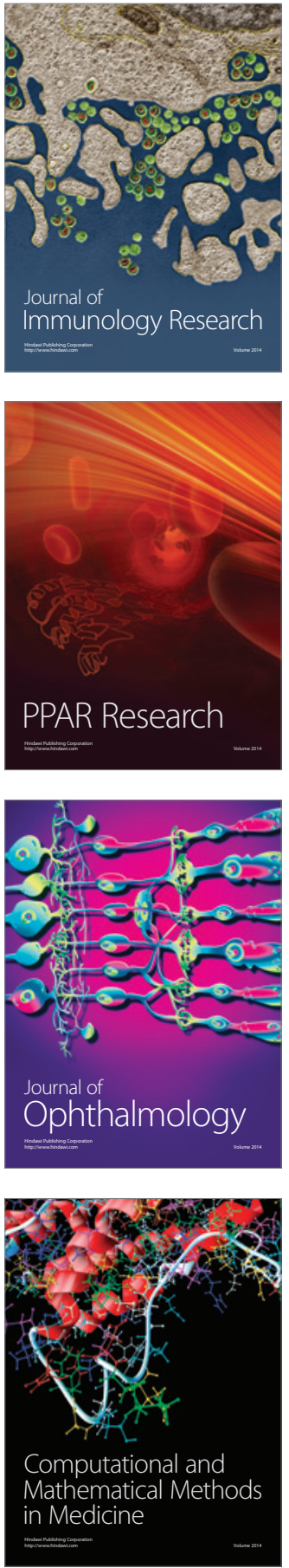

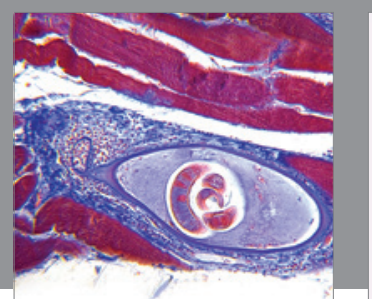

Gastroenterology Research and Practice

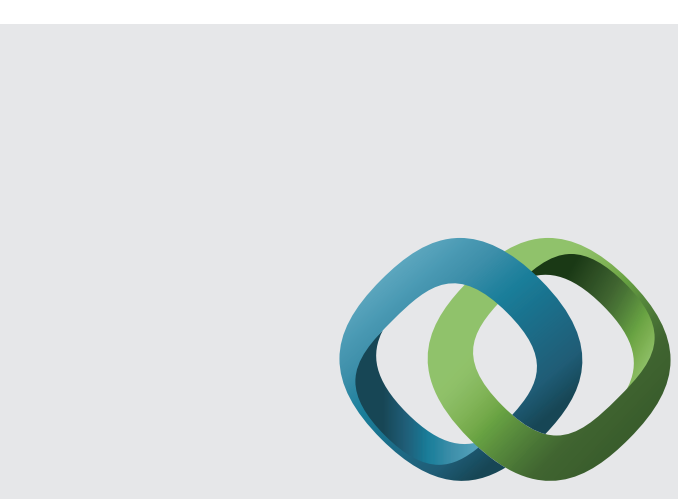

\section{Hindawi}

Submit your manuscripts at

http://www.hindawi.com
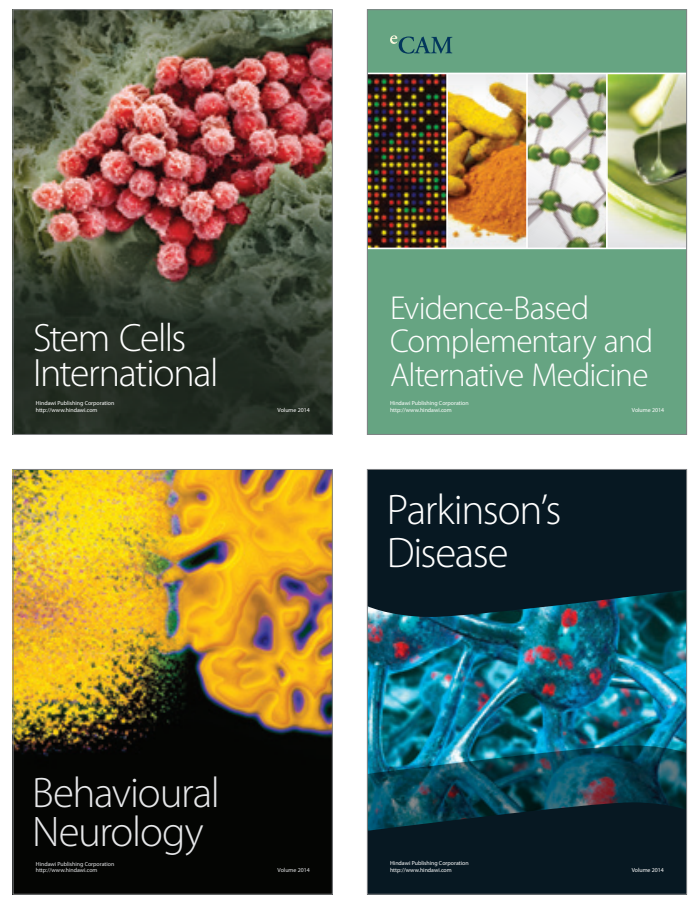
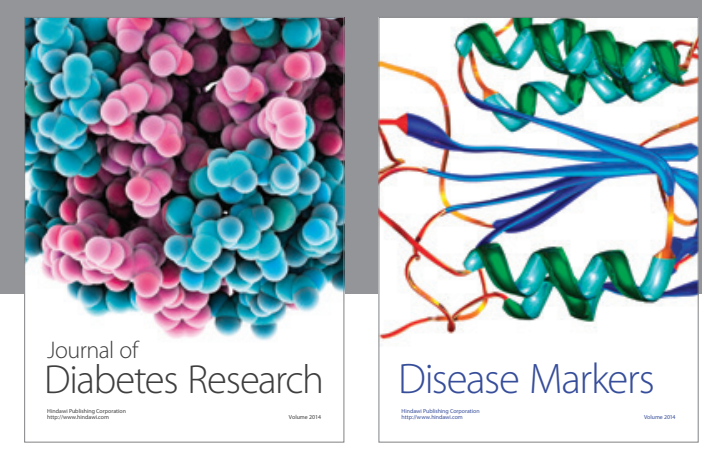

Disease Markers
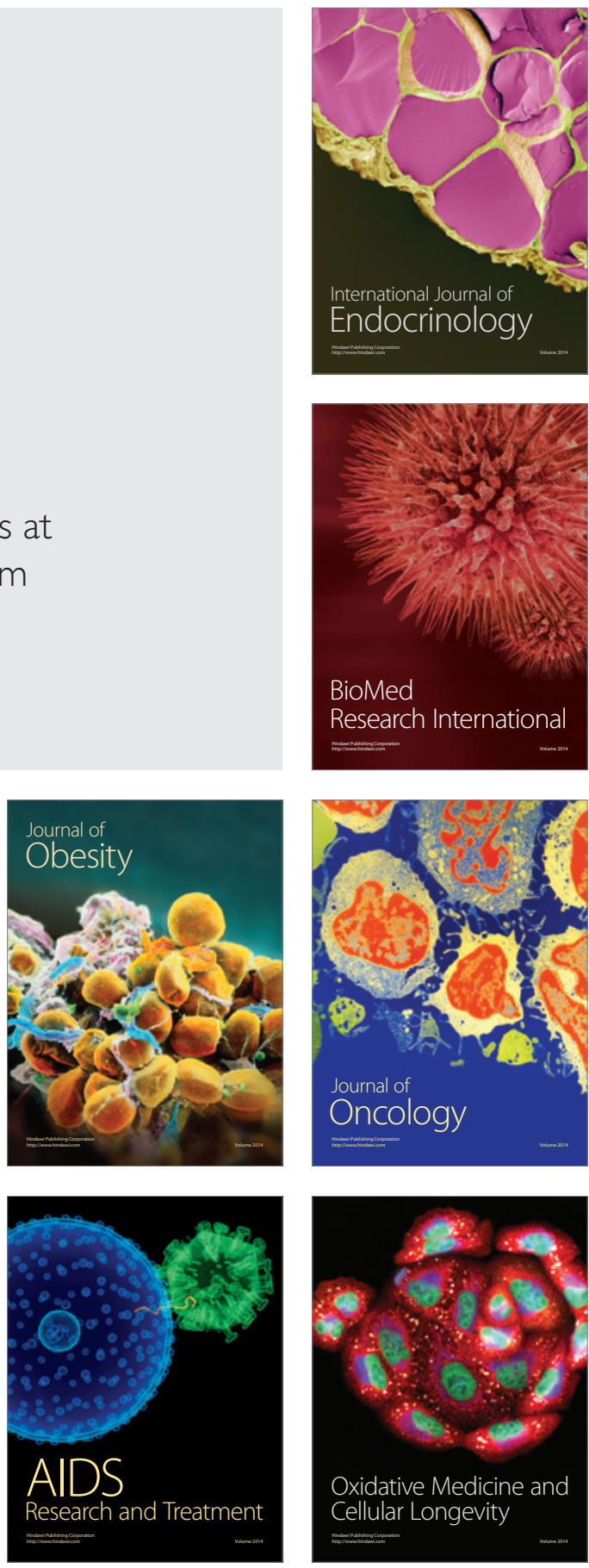